\title{
Islamic Monetary Policy and its Impact on the Growth of Islamic Banking (Case Study in Indonesia)
}

\author{
Yoghi Citra Pratama \\ Islamic Economics Studies Program \\ Universitas Islam Negeri Syarif Hidayatullah Jakarta \\ yoghi@uinjkt.ac.id
}

\begin{abstract}
Islamic economics as a new field in the modern economic science recognizes not only the principles and operations of Islamic commercial banks but also central bank as the monetary and economic authority. Amongst all, the main functions of a central bank in Islam are to maintain price stability and prosperity of the whole people. Although it seems indifferent with the conventional concept of central bank, the Islamic central bank conducts its monetary operation by using Islamic monetary instruments which are free from interest, links with the business sector activities and gives value added into the economy. The progressive development of the Islamic banking industry demands the appropriate Islamic monetary instruments to control the industry and economy in general The aim of this paper is to review Islamic monetary policy and Its Impact to the development on Islamic Banking in Indonesia. The method used in this study is an examination of existing literature.
\end{abstract}

Keywords: Islamic Monetary Policy, Islamic Banking

\section{INTRODUCTION}

Islamic economics as a new field in the modern economic science recognizes not only the principles and operations of Islamic commercial banks but also central bank as the monetary and economic authority. Amongst all, the main functions of a central bank in Islam are to maintain price stability and prosperity of the whole people [1]. Although it seems indifferent with the conventional concept of central bank, the Islamic central bank conducts its monetary operation by using Islamic monetary instruments which are free from interest, links with the business sector activities and gives value added into the economy [2].

Since the issuance of new Banking Act 1998, Indonesia in de jure has implemented a dual banking system, when conventional and Islamic banks can operate side by side throughout Indonesia. Meanwhile, since the issuance of the new Bank Indonesia act in 1999, Bank Indonesia has been given the responsibility as the dual monetary authority that can operate conventional and Islamic monetary policy. Since then banking and Islamic financial growing rapidly [3].

Dual banking system adopted by Indonesia in the monetary system allows Bank Indonesia has a more various channels to reach the ultimate goal. Monetary policy based on syariah is assessed that can provide better methods on enhance the asset of Islamic Banking. Influence of monetary authority action against the growth of Asset of Islamic Banking occurs through various channels, such as policy of Islamic banking act, money channel or direct channel, interest/ profit sharing channel, credit/financing channel, exchange rate channel, asset price channel and expectation channel. In finance, monetary policy affects the development of interest rates, exchange rate and stock prices as well as volume of public funds deposited in the bank, bank lending to the business, investment funds in bonds and stocks. Meanwhile, in real sector, monetary policy further affect consumption, investment and production, exports and imports, as well as the prices of goods and services in general. Despite a fast growing Islamic banking industry, the implementation of monetary policy and the transmission mechanism of monetary policy in the presence of Islamic banks remain a challenge for the central banks $(\mathrm{CBs})$. The challenges arise how to make policies to encourage Islamic Banking Asset growth significantly.

The development of the Indonesian Islamic Banking Industry is conducted under dual banking system (conventional and Islamic banking system) in the micro and macro frameworks. The Islamic banking industry has been growing very well since the establishment of the first Islamic bank in 1992. The education of people to use Islamic Bank is spurred on by the council of Indonesia sharia Scholars (MUI) and the Muhammadyah organization, who issued verdicts on the prohibition of interest on December 16, 2003, and April 3, 2010. [4]

Nevertheless, the progressive development of the Islamic banking industry demands the appropriate Islamic monetary policy to encourage the growth of industry and economy in general. The growth of Islamic banking, and improve the quality of its human resources is also explained by Febrian [5]. Almost the same as febrian, Zubair [6] stresses the roles of legal aspects (banking regulations), social acceptance, innovation of banking products, and an increase in the number of offices as the triggering factors to speed up the growth of the industry. Finally, Samitasiwi and Cahyadin [7] study the prospect of the industry, which is found very prosperous based on the future performance of total assets, total deposits, and total financing from the estimation period of third quarter of quarter of 2008

Bank Indonesia (BI) as the monetary authority institutions has a variety instrument and policy in determining monetary instrument to enhance the growth of Islamic Banking. The process of monetary policy in affecting the growth of Islamic 
Banking, is a complex process because the money is closely related to almost all aspects of the economy. Monetary policy is a complex and interest topic because there is not one, but many aspect that influence the growth of Islamic banking in Indonesia. Effectiveness of the monetary policy is varied and from time to time, depending on the economic condition and financial structure. Although monetary transmission channels have different effect to the real economy, there is also the relationship between the channel through which they can enhance or negate the effect of another channel in the process of monetary transmission, depending on the structure of economy and financial structure. Effectiveness of some monetary transmission mechanisms are varied and evolve over the time [8].

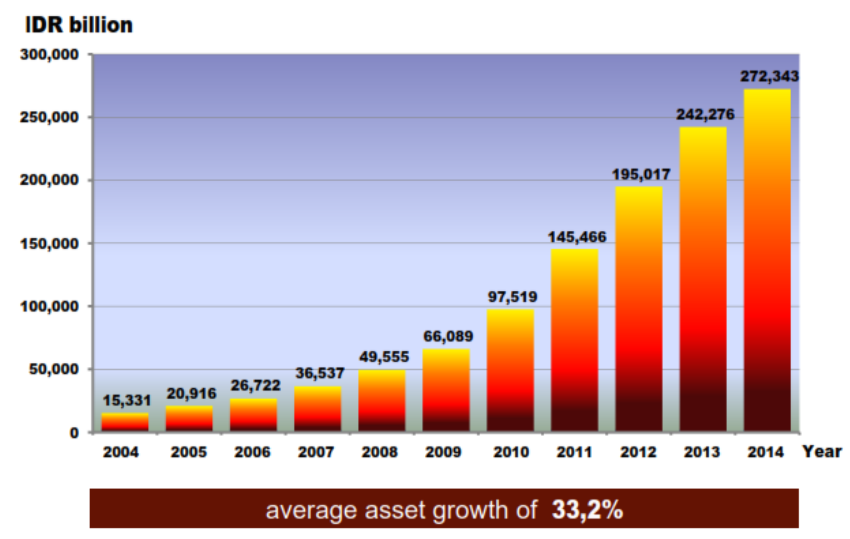

Fig. 1. Islamic Banking Asset Growth.

From that graph it can be shown that the growth of Asset of Islamic Banking in Indonesia had increased with average asset growth 33, $2 \%$ for ten years from 2004 to 2014. In 2004 the asset of Islamic Banking was 15, 531 Billion Meanwhile in 2014 the asset increased significantly for 273,343 billion Rupiah. However if compare to the asset of conventional bank the asset of Islamic Banking only have market share 4,8 percent in 2014, and that not fullfill the target of goverment which determined the target $5 \%$ market share in 2012.

During the period of 2004 to the end 2007, the growth of Islamic Banking indicators, the growth of Islamic banking indicators was affected and determined by unpleasent and pleasent economic conditions. Firts, the fast performance of indicators in the earlier years was later on slowed down due to unpleasent economic conditions in 2005 and 2006. Total asset rose 70 percent on average per year in 2000 to 2004, but these gains were eroded due to negative impact of the world oil price hike on the domestic economy. However, after that turbulance (2006 to 2007) the economy recovered and the performance of Islamic Banking indicators rebounded as well. The average annual growth assets in 2006 to 2006 plumeted 28 statage of total asset from 2000 to 2004 , followed by the stage of decline in 2005 and 2006, and rebounding stage from 2006 to 2007[4].

Financial systems where Islamic banking is systemic are typically dual and not fully developed. Islamic banks tend to develop side-by-side conventional banks and are influenced by "standard" monetary policy instruments and conditions. As Islamic finance grows in importance, development in that segment may start to influence, under competitive pressure, the conventional financial system and overall market conditions. Islamic banks are not isolated from the macrofinancial background in which they operate: exogenous shocks, macroeconomic management, and systemic liquidity conditions have implications for monetary policy implementation and its transmission through the Islamic banking system. Assessing monetary policy effectiveness in the presence of Islamic banking is complex, as it requires examining it through multiple and sometimes conflicting dimensions. These include: the fundamental Islamic principles of ex-ante interest payment prohibition and profit-and-risk sharing; the spillovers from the conventional segment to the Islamic segment of the financial system; and the monetary policy framework and instruments in place. As in conventional systems, monetary policy in the presence of Islamic banking needs to adequately address structural excess liquidity, financial system shallowness, and fiscal dominance issues. Dominant public sectors, direct monetary financing of fiscal deficits, or distorted credit environments also limit the scope of monetary policy transmission through Islamic banks. Monetary policy mainly works through prices or quantities.

When conducting monetary policy in the presence of Islamic banks, caution is required in assessing the monetary transmission mechanism. Islamic financial systems are heterogeneous: they can be full-fledged Islamic or they can be developing side by side a more-or-less mature conventional banking system. Introducing Islamic banks in macrofinancial environments where the interest rate channel is well established can result in conventional monetary policy transmission through the Islamic financial system, even if this transmission has not been anticipated by the CB. In full-fledged Islamic financial systems, monetary policy transmission could be activated through the credit channel as long as the CBs' actions affect the supply of Islamic credit. However, the bank lending channel-or financing channel for Islamic banks-may eventually weaken with financial liberalization and financial markets development. Another important consideration is the extent to which the $\mathrm{CB}$ can influence the funding costs of Islamic banks by targeting the profit-sharing ratio of interbank Mudarabah markets.

This study aims to test the validity of the above proposition by providing empirical evidence on this issue. To achieve this objective, this study analysis the impact of monetary policy to the Islamic Banking growth in Indonesia. As mentioned, while most of the existing literature in this area focuses on the implematation of monetary policy through policy instruments that are consitent with the Islamic law or the shari'ah, this study offers a new dimension by assessing the impact of monetary policy on the Islamic financial instruments that are consistent with the Islamic law or the shari'ah. This would allow for several inferences to be made about the stability and viability of the Islamic financial instruments for monetary policy implementation purposes. Another aspect of novelty of terms of its methodology. This study analysis monetary policy and several literature to arrive at conclusive findings on this issue. In this regard, the study contributes in enriching the empirical literature in the area of monetary policy from the Islamic perspective. 


\section{RESEARCH METHODOLOGY}

This research aims to explore, explain and examine the impacts of Islamic monetary policy to the growth of Islamic banking, by studying the policy, rules literature perception of the current methods, tools and strategies applied by the industry. Therefore, this research adopts a qualitative research methodology as the main research frame and process to fullfill and the research aims and objectives and answer the research questions.

The qualitative research methodology is an approach used to describe and interpret a specific phenomenon. Bryman [9] defines qualitative research as "an approach to the study of the social world which seeks to describe and analyze the culture and behavior of humans and their groups from the point of view of those being studied". This approach emphasises on the human aspect and how people see, perceive and understand social phenomena as they occur in the certain situations. It is mainly used when a researcher's motivation is to describe, explain or evaluate a phenomenon. Thus, the qualitatative research methodology is used where the emphasis is on words instead of quantifiable data [9].

\section{RESULT AND DISCUSSION}

The chief role of monetary policy and of central banking in an Islamic system is to take the lead in evolving financial institution and instruments that facilitate efficient mobilization of savings and allocation of resources consistent with the economic development objectives of the Islamic economy. The central bank, in particular, must initiate and foster the development of primary, secondary, and money markets. Mere adoption of islamic rules of finance will not necessarily create the impetus for financial and economic development where the shallowness of financial markets and lack of attractive financial instruments have created impediments to the savinginvestment nexus and for the process of financial intermediation[10]. The roles of monetary policy become very important to support the growing of Islamic institution, include the Islamic Bank.

Indonesia already issued several monetary policy to enhanced the growth of Islamic Banking in Indonesia, however that policy weren't enough to make Islamic Bank grew as we expected. It can be seen from the growth of Islamic bank asset that still lower than the target from goverment which reach five percent market share in 2012. Till now we only have $4.8 \%$ market share.

The regulatory framework for Islamic banking must accommodate the basic character of Islamic banking at the same time regulate the common issues to all financial intermediary institutions such as management contracts, bankruptcy, collateral, and asset recovery. Islamic banking regulation also should give clear definition of the institution of Islamic banks in line with the licensing requirements, capital, scope of activities, and its relationship with the regulatory authorities. Islamic banking regulation must also be able to identify, assess and manage the risks inherent in Islamic banking activities.

\section{POLICY BEFORE THE ISLAMIC BANKING ACT 2008}

Policy implementation in the area of Islamic banking development is continuously applied to enhance contribution of Islamic banking in real economic development and efficient financial transactions to achieve prosperity of people. And Indonesia started in 2006 to implement development programs and monetary financial instruments based on sharia involving various work units in Bank Indonesia planned to be implemented multiyear. Stages of development of monetary and financial instruments based on sharia is as follows [11]:

- Phase I activities (2006) focused on the preparation of various studies underlying the monetary and financial aspects.

- Phase II of the project (2007) focused on the preparation of the implementation of the recommendations of the studies both within Bank Indonesia and provide technical recommendations to the relevant agencies in terms Implements Islamic financial instruments.

- Phase III activities (2008) expected the whole concept is built can be implemented in their entirety.

Under the law No. 23 of 1999 concerning Bank Indonesia, the monetary policy conducted by Bank Indonesia can use the instrument operation is based on Islamic principles. In relation to that, Bank Indonesia issued several regulations that are encouraging the development of Islamic interbank money market and monetary instruments for Islamic Banking, namely:

\begin{tabular}{|c|c|c|}
\hline \multicolumn{2}{|r|}{ TABLE I. } & \multirow{2}{*}{ ISLAMIC MONETARY INSTRUMENT BEFORE 2008} \\
\hline No & Instrument & \\
\hline \multirow[t]{3}{*}{1} & \multirow{3}{*}{$\begin{array}{l}\text { GWM } \\
\text { Syariah } \\
\text { (Sharia } \\
\text { Minimum } \\
\text { Statutory } \\
\text { reserves) }\end{array}$} & $\begin{array}{l}\text { PBI No. 2/7 / PBI / } 2000 \text { concerning Statutory } \\
\text { Reserves in Rupiah and foreign currency for } \\
\text { commercial banks conducting business based on } \\
\text { Sharia principles }\end{array}$ \\
\hline & & $\begin{array}{l}\text { PBI No. 6/21 / PBI / } 2004 \text { on Statutory Reserves in } \\
\text { Rupiah and Foreign Currency for Commercial } \\
\text { Banks conducting business based on Sharia } \\
\text { principles; revoke PBI No. } 2 / 7 \text { / PBI / } 2000\end{array}$ \\
\hline & & $\begin{array}{l}\text { BI No. 8/23 / PBI / } 2006 \text { Amendment of PBI No. } \\
6 / 21 \text { / PBI / } 2004\end{array}$ \\
\hline \multirow[t]{2}{*}{2} & \multirow{2}{*}{$\begin{array}{l}\text { SWBI (Bank } \\
\text { Indonesia } \\
\text { Sharia } \\
\text { Certificates) }\end{array}$} & $\begin{array}{l}\text { PBI No. 2/9 / PBI / } 2000 \text { on Bank Indonesia Wadiah } \\
\text { Certificates }\end{array}$ \\
\hline & & $\begin{array}{l}\text { PBI No. 6/7 / PBI / } 2004 \text { on Bank Indonesia Wadiah } \\
\text { Certificates }\end{array}$ \\
\hline 3 & $\begin{array}{l}\text { SBI Syariah } \\
\text { (Bank } \\
\text { Indonesia } \\
\text { Sharia } \\
\text { Certificates) }\end{array}$ & $\begin{array}{l}\text { PBI No. 10/11 / PBI March 31, } 2008 \text { on Bank } \\
\text { Indonesia Certificates Sharia; revoke PBI No. 6/7 / } \\
\text { PBI / } 2004\end{array}$ \\
\hline \multirow[t]{5}{*}{4} & \multirow[t]{5}{*}{ FPJP Syariah } & $\begin{array}{l}\text { BI No. 5/3 / PBI / } 2003 \text { regarding Short Term } \\
\text { Financing Facility for Sharia Banks (FPJPS) }\end{array}$ \\
\hline & & $\begin{array}{l}\text { PBI No.7 / } 23 \text { / PBI / } 2005 \text { regarding the } \\
\text { amendment of Regulation No. 5/3/ PBI } 2003 \text {. }\end{array}$ \\
\hline & & $\begin{array}{l}\text { BI No. 11/24 / PBI / } 2009 \text { on short-term funding for } \\
\text { the Sharia Islamic Banks, revoke PBI 5/3 / PBI / } \\
2003 \text { and 7/23 / PBI / } 2005 \text {. }\end{array}$ \\
\hline & & $\begin{array}{l}\text { PBI No.11 / } 29 \text { / PBI / } 2009 \text { on short-term funding } \\
\text { for sharia banks financing. }\end{array}$ \\
\hline & & $\begin{array}{l}\text { PBI No. 14/20 / PBI / } 2012 \text { regarding the } \\
\text { amendment of Regulation No. } 11 / 24 / \text { PBI / } 2009 .\end{array}$ \\
\hline 5 & FLI Syariah & $\begin{array}{l}\text { PBI No.7 / } 24 \text { / PBI / } 2005 \text { concerning Intraday } \\
\text { Liquidity Facility for Commercial Banks Based on } \\
\text { Sharia principles. }\end{array}$ \\
\hline
\end{tabular}


Relying on market-based instruments to conduct monetary policy in an economy with Islamic banks is preferable than relying on direct instruments of monetary control for both conventional and Islamic banks. Direct instruments are often associated to non-transparent discretionary interventions that may result in a liquidity misallocation. They can create distortions in favor of some sectors of the economy or segments of the banking system, impairing banks competition and interbank markets development. When implemented in a surplus liquidity situation without an appropriate liquidity forecasting framework, direct instruments of monetary control can aggravate the liquidity overhang. To incorporate Islamic banks in the monetary policy framework, two important dimensions need to be considered. The first one is the challenge of developing the basic infrastructure necessary for a market-based Islamic monetary policy. The second is addressing more broadly the continuous evolution of the monetary policy framework. Developing Islamic money and Sukuk markets, as well as addressing the factors that give rise to market segmentation belong to the first dimension. Addressing potential spillovers from one segment of the financial system to another has implication for the monetary policy and financial stability. Competition among Islamic banks is a precondition for the development of Islamic interbank markets. A small number of Islamic banks or a dominant role of government owned banks limits the scope of interbank market development and monetary transmission more generally. Market segmentation between conventional and Islamic banking systems can be a challenge for the conduct of monetary policy. In some countries with dual banking systems, Islamic banks are not participating in CB's conventional monetary operations and interbank markets, creating segmentation between Islamic and conventional money markets. While conventional banks use several money markets instruments to manage efficiently their liquidity, Islamic banks face greater difficulties as they cannot access markets that do not comply with the Islamic finance rules. Inefficient liquidity management reduces Islamic banks profitability, as they need to maintain more liquidity than strictly necessary.

The IFSB Technical Note on Islamic Money Markets argues that there is an evidence of market segmentation between Islamic and conventional banking systems, as IIFS rely primarily on interbank arrangements with other IIFS, with limited usage of transactions between IIFS and conventional banks. This segmentation can hamper the well-functioning and development of liquid money markets particularly when the number of Islamic banks in the system is small. IIFS usually represent a small share of the overall financial system in dual financial systems and interbank market instruments that are limited to Islamic financial institutions alone seldom have the scale and volume needed to generate a liquid interbank market. Active Islamic interbank markets are crucial for monetary policy transmission through the Islamic financial system. Interbank markets allow liquidity to circulate through the banking system and reach its most needing segments. Developed interbank Mudarabah markets allow the transmission of monetary policy changes through profit-sharing ratios. Active FX interbank markets are also important for monetary policy transmission through the exchange rate channel [11].

\section{POLICY OF ISLAMIC BANKING DEVELOPMENT IN INDONESIA} AFTER 2008.

As from June 17, 2008, Indonesian sharia banking industry officially entered a new era. Islamic Banking bill that has been entered into the House since mid-2005 as an initiative of the House bill, has passed so that Indonesia is now officially has the regulation of Islamic banking namely Law No. 21 of 2008 concerning Islamic Banking. Islamic Banking Act as the regulation of Islamic banking, have a lot of arguments. The main rationality is a systemic considerations, the failure of a bank would be important implications on the stability of the financial system and the overall economy. Islamic Banking Act will also be important to protect consumers / customers. Banks must keep the risks to be rational and caution in investment decisions, avoid mis management, and taking no action at high risk [12].

In 2008 Bank Indonesia make the necessary arrangements for the provision of monetary instruments for Islamic banking. The grounds of fair treatment and the unity of monetary policy signals, Bank Indonesia issued Bank Indonesia Regulation Number 10/11 / PBI / 2008 on certificates of Bank Indonesia Sharia on 31 March 2008. PBI is a refinement of sharia monetary operations framework. Such revision started in April 2008 with the introduction of Sharia as a replacement SWBIs SBI which has been used since 2000. The other consideration for such reimbursement is increasing the effectiveness of Islamic banking liquidity absorption activity as part of operations moneter Bank Indonesia. In addition to the improvement of the contract used, from wadiah be fast approaching, there is a mechanism that significantly changed the operation of the window (standing facility) into the auction (non-competitive bidding).

After the passing of law No. 21 of 2008 concerning Islamic banking on July 16, 2008, and in order to provide a legal basis more established for monetary instruments, Bank Indonesia as a monetary authority issued a regulation that encourages the development of the money market and monetary instruments for Islamic banking [11].

From table 2 can be seen that BI already issued more liquidy instrument to establish Islamic Banking. The reguler demand for liquidity can be managed by having cash reserves while the irregular demand for liquidity can be solved by selling short and long term Islamic securities, borrowing funds from the Islamic money market, borrowing funds from the parent company and shareholders, and employing the central bank emergency liquidity fund [4].

\section{ISLAMIC BANKING DEVELOPMENT IN INDONESIA}

Various aspects have been taken comprehensively into consideration such as the actual condition of national Islamic banking industry including related tools, development trend of Islamic banking industry within international scale as well as system development of national Islamic finance. Islamic Banking that has started to be materialized and inseparable 
from wider architectural landscape such as Indonesian Banking Architecture (API) and Indonesian Financial System Architecture (ASKI), including international best practices formulated by international Islamic financial institutions such as IFSB (Islamic Financial Services Board), AAOIFI and IIFM.

TABLE II. ISLAMIC MONETARY INSTRUMENT AFTER 2008

\begin{tabular}{|c|c|c|}
\hline No & Instrument & Provision \\
\hline \multirow[t]{2}{*}{1} & \multirow[t]{2}{*}{$\begin{array}{lr}\text { GWM } & \text { Syariah } \\
\text { (Sharia } & \text { Minimum } \\
\text { Statutory } & \text { reserves) }\end{array}$} & $\begin{array}{l}\text { PBI No.10 / } 23 \text { / PBI / } 2008 \text { regarding the } \\
\text { Second Amendment to Bank Indonesia } \\
\text { Regulation No. 6/21 / PBI / } 2004 \text { Statutory } \\
\text { Reserves in rupiah and foreign currencies to } \\
\text { commercial banks conducting business based } \\
\text { on sharia principles }\end{array}$ \\
\hline & & $\begin{array}{l}\text { PBI No.15 / } 16 \text { / PBI / } 2013 \text { on Statutory } \\
\text { Reserves in rupiah and foreign currencies for } \\
\text { Commercial banks and Islamic business units }\end{array}$ \\
\hline \multirow[t]{2}{*}{2} & $\begin{array}{ll}\text { SBI Syariah } & \text { (Bank } \\
\text { Indonesia } & \text { Sharia } \\
\text { Certificates) } & \end{array}$ & $\begin{array}{l}\text { PBI No.12 / 18 / PBI / } 2010 \text { dated August 30, } \\
2010 \text { concerning amendment of PBI No.10 / } \\
11 \text { / PBI / } 2008 \text { on certificates of Bank } \\
\text { Indonesia Sharia }\end{array}$ \\
\hline & & $\begin{array}{l}\text { PBI No.16 / } 12 \text { / PBI / } 2014 \text { on sharia } \\
\text { monetary operations; governing the contract } \\
\text { and the characteristics of SBIS, SBIS repo, } \\
\text { and administration of SBIS; revoke PBI No. } 10 \\
\text { / } 11 \text { / PBI / 2008 on Bank Indonesia } \\
\text { Certificates Sharia }\end{array}$ \\
\hline \multirow[t]{3}{*}{3} & \multirow[t]{3}{*}{ FPJP Syariah } & $\begin{array}{l}\text { PBI No. 11/24 / PBI / } 2009 \text { on short-term } \\
\text { funding facility for Commercial Bank Islamic } \\
\text { Sharia; revoke PBI No.7 / } 23 \text { / PBI / } 2005\end{array}$ \\
\hline & & $\begin{array}{l}\text { PBI No. 11/29 / PBI / } 2009 \text { on financing } \\
\text { facilities Short Term } \\
\text { financing }\end{array}$ \\
\hline & & $\begin{array}{l}\text { PBI No. 14/20 / PBI / } 2012 \text { on Amendments to } \\
\text { Regulation No. 11/24 / PBI / } 2009\end{array}$ \\
\hline \multirow[t]{2}{*}{4} & \multirow[t]{2}{*}{ FLI Syariah } & $\begin{array}{l}\text { PBI No.7 / } 24 \text { / PBI / } 2005 \text { Intraday Liquidity } \\
\text { Facility for Commercial Banks Based on } \\
\text { Sharia principles }\end{array}$ \\
\hline & & $\begin{array}{l}\text { PBI No. 11/30 / PBI / } 2009 \text { on intraday } \\
\text { liquidity facility based on Islamic principles } \\
\text { (FLIS); revoke PBI No.7 / } 24 \text { / PBI / } 2005\end{array}$ \\
\hline \multirow[t]{2}{*}{5} & FASBI Syariah & $\begin{array}{l}\text { PBI No. 10/36 / PBI / } 2008 \text { on sharia } \\
\text { monetary operations }\end{array}$ \\
\hline & & $\begin{array}{l}\text { PBI No. 16/12 / PBI / } 2014 \text { concerning Sharia } \\
\text { Monetary operations; revoke PBI No. 10/36 / } \\
\text { PBI / 2008, PBI 12/17 / PBI / } 2010 \text { and PBI } \\
\text { No.13 / } 24 \text { / PBI / 2011 }\end{array}$ \\
\hline 6 & $\begin{array}{l}\text { Term } \\
\text { Syariah }\end{array}$ & $\begin{array}{l}\text { PBI No.16 / } 12 \text { / PBI / } 2014 \text { on sharia } \\
\text { monetary operations'; revoke PBI No. 10/36 / } \\
\text { PBI/2008. PBI No. 12/17 / PBI / } 2010 \text { and PBI } \\
\text { No.13 / 24 / PBI / 2011 }\end{array}$ \\
\hline
\end{tabular}

In the condition of its integration, in the short term, the phase of Islamic banking development is more directed toward servicing the huge potential of domestic market. In other words, Indonesian Islamic banking tried to be able to become domestic player with an international quality in services and performance. Subsequently, the Islamic banking system envisioned by Bank Indonesia is a modern Islamic banking with open and universal characteristics and inclusive to all Indonesian people with no exception. It refers to banking system presenting applicative forms of Islamic economic concept that is wisely formulated in the current context of problems faced by Indonesia within the consciousness of the historical socio-cultural condition of this country. Only by doing that, the aspiration development of Islamic banking will always be recognized and accepted by all Indonesian people as a part of the solutions to the various problems encountered by this country.

In line with the concrete efforts in developing Islamic banking in Indonesia, Bank Indonesia has formulated a Grand Strategy of Islamic Banking Market Development, as a comprehensive strategy of market development covering strategic aspects, such as: determining the vision of 2010 as the leading Islamic banking industry in ASEAN, creating the new image of inclusive and universal Islamic banking, mapping a more accurate market segment, developing more various products, improving services as well as adopting new communication strategy of Islamic banking by positioning it as a beyond banking position. (Islamic banking is more than just a bank).

Hence, different concrete programs have and will be performed as the implementation stage of the Grand Strategy of Islamic Banking Market Development including but not limited to the following measures [14]:

First, assigning a new vision of Islamic banking development on phase I in 2008 to build understanding in Islamic banking as Beyond Banking by reaching an asset target of Rp 50 trillion and industrial growth of 40\%, phase II in 2009 with the objective of positioning Indonesian Islamic banking as the most attractive one in ASEAN. Phase III in 2010 will have the objective of attaining Indonesian Islamic banking as a leading Islamic Bank in ASEAN.

Second, new image program of Islamic banking that includes positioning, differentiation and branding aspects. The new positioning of Islamic bank as banking that provides mutual benefits to both parties, differentiation aspect with competitive advantages with various products and schemes, transparency, competent and ethical finance, updated and user friendly information technology as well as qualified investment expert of Islamic finance. Branding aspect will be represented by "Islamic bank, more than just a bank "(beyond banking).

Third, new mapping program which is more accurate on Islamic banking market potential that generally directs Islamic bank services as universal service or bank accessible for all kinds of people and all segments in accordance with the strategy of each Islamic bank.

Fourth, product development program directed to various products variations supported by the unique value offered (mutual benefits) and strengthened by a wide office network and the use of easily comprehended standards of product name (example : deposit - iB, financing - iB).

Fifth, program of service quality enhancement supported by competent human resources and the supply of information technology to meet customer's requirement and satisfaction. This competency is also expected to be able to communicate products and services of Islamic banking to customer correctly and clearly get always complying to sharia principles; and 
Sixth, a wider and more efficient socialization and educational program for public interest through various direct or indirect (printing and electronic media, online/website) communication channels with the objective of contributing comprehension on the advantages of Islamic banking products and services that can be benefited by the public.

From that fact and data, it can be known that regulation to support it has not shown a corresponding growth. There is a need to relook at the current regulations and guidelines in order to bring it at par with the development of Islamic banking worldwide. For example, the judiciary must have a dedicated unit to handle Islamic banking legal cases should it go to the court for adjudication. So that, monetary policy and regulations for Islamic banking are challenge for the authorities in order to understand and balance between effective supervision and facilitating the industry's growth and further development. At the same time, regulation of the industry is the need for level playing field, an effective infrastructure, serves its markets and penetration into the global markets.

\section{CONCLUSION}

Objective of the discussion in this article is to evaluate the policy of monetary that can encourage the growth of Islamic Banking in Indonesia. The Islamic banking Industry in Indonesia faces remarkable growth and performances. It has set the target market share of 5 percent since 2007 but as of the end of 2015 the target still cannot be achieved. Meanwhile, the banking regulators and all stakeholders continue to intend to position the Indonesian Islamic Banking Industry as the most attractive in ASEAN and the leader in ASEAN in. However, some challenges need to be mitigated before such a target can be easily realized. Three extra strategic policies are proposed to complement the ongoing programs of developing the Islamic Banking industry, namely converting one or more state-owned banks, attracting high-net-worth individuals, and increasing the engagement of the government in the industry. However, the success of all efforts requires the involvement of all parties and favorable economic/business conditions to make the industry more meaningful in the years to come. The evaluation is done through the analysis of the impact of monetary policy to the growth of Islamic Banking in Indonesia since at the beginning of Islamic banking appear in Indonesia.

\section{REFERENCES}

[1] Chapra, U., Toward Just a Monetary System, Islamic Foundation, Leicester, 1985

[2] Mills, P. and Presley, J., Islamic Finance: Theory and Practices, Palgrave McMillan,New York, NY, 1999

[3] Ascarya., Alur Transmisi dan Efektifitas Kebijakan Moneter Ganda di Indonesia. Jakarta : Buletin Ekonomi Moneter dan Perbankan, 2012

[4] Ismal, Rifki., Islamic Banking in Indonesia New Perspective on Monetary and Financial Issues. Willey Finance Series. Singapore,2013

[5] Febrian,Erry., Accelerating the Growth of National Islamic Banking : Challenge and Contribution of the Higher Education Institutions,"www.stmik-im.ac.id/,2008

[6] Zubair, Muhammad Kamal., "Acceleration of the Growth of Islamic Banking in Indonesia," Journal Millah 8, no. 1.2008.

[7] Sasmitasiwi,Banoon, and Malik Cahyadin., The Prediction of Shari'ah Banking Growth in Indonesia, Iqtisod International Journal of islamic Economics 10, no.1,2009.

[8] Cevik, Serhan and Teksoz, Katerina., Lost in Transmission? The Effectiveness of Monetary Policy Transmission Channels in the GCC Countries. IMF Working Paper Indonesia. Jakarta: Bank Indonesia, 2012

[9] Bryman, Alan, Social Research Methods, third edition, Oxford University Press, 2008.

[10] Khan, Mohsin S and Mirakhor, Abbas., Monetary Management in an Islamic Economy, Islamic Econ, Vol 6. International Monetary Fund, Washington D.C. 1994.

[11] Bank Indonesia., Perjalanan Perbankan Syariah di Indonesia. Grup Riset Kebanksentralan Bank Indonesia, 2016.

[12] Wibisono, Yusuf,.Politik Ekonomi UU Perbankan Syariah Peluang dan Tantangan Regulasi Industri Perbankan Syariah. Jurnal Ilmu administrasi dan Organisasi. Vol 16 no 2.2009.

[13] Khatat, Mariam El Hamiani., Monetary Policy in the Presence of Islamic Banking. IMF Working Paper, 2016.

[14] Bank Indonesia., Grand Strategy of Islamic Banking Development, Directorate of Islamic Banking Bank Indonesia, 2008. 